\title{
Morphological and histological studies on the pituitary gland of Liza carinata from the Suez Bay (Red Sea, Egypt), with special reference to the gonadotrophs
}

\author{
Fawzia A. A. Abd El-Rahman ${ }^{1}$, William Rizkalla ${ }^{1}$, Hamza A. El-Shabaka ${ }^{1}$, \\ Azza A. El-Ganainy ${ }^{2}$ and Mazaya E. Abo-Mosallam ${ }^{1}$ \\ 1- Department of Zoology, Faculty of Science, Ain Shams University, Abbassia, Egypt. \\ 2- National Institute of Oceanography and Fisheries, Suez branch, Egypt.
}

\section{ABSTRACT}

The teleosts pituitary gland has a peculiar structure that shows wide variability of its morphology and cellular organization. Moreover, the pituitary gland usually displays seasonal changes during the reproductive cycle. So, the present study is designed to identify and localize the different cell types of the pituitary gland of mature male and female of Liza carinata from the Suez Bay and to study the possible variations that found during its reproductive cycle.

The result revealed that the pituitary gland of $L$. carinata is of the platybasic type, which lacks a distinct hypophyseal stalk, and is differentiated into two main divisions, namely: the adenohypophysis and neurohypophysis. The glandular adenohypophysis consists of five main cell types, the lactotrophs, somatotrophs, gonadotrophs, thyrotrophs and melanotrophs. On the other hand, the neurohypophysis is formed of nerve fibres and contains a variable amount of neurosecretory granules. Moreover, the principal seasonal variations take place in the meso-adenohypophyseal gonadotrophs and the neurosecretory granules.

Keywords: Pituitary gland, Liza carinata, gonadotrophs, adenohypophysis, neurohypophysis.

\section{INTRODUCTION}

Pickford \& Atz (1957) and Khan (1962) distinguished three regions of the pars glandularis of the pituitary gland of Anguilla anguilla and Labeo rohita, respectively, namely: the pro-, meso-and meta- adenohypophyses. Moreover, Ekici and Timiur (2013) stated that the pituitary gland of Cyprinus carpio is composed of a nervous part, the neurohypophysis, and a glandular part, the adenohypophysis. Furthermore, they pointed out that the adenohypophysis is divided into rostral pars distalis, proximal pars distalis and pars intermedia which are arranged in a linear fashion with the rostral pars distalis at the anterior extremity. Furthermore, de Jesus et al. (2014) stated that the adenohypophysis of Salminus brasiliensis is directly innervated by branches of the neurohypophysis.

Jose and Sathyanesan (1977) described eight cell types in the adenohypophysis of Labeo rohita. These are two acidophilic types, five basophilic types and a chromophobic one. On the other hand, Sahai (1984), Munro (1985) and Narayan et al. (1985) distinguished six different cell types in the pituitary gland of Osteobrama cotio, Aequidens pulcher and Mugil cephalus, respectively, namely: the lactotrophs, corticotrophs, melanotrophs, somatotrophs, thyrotrophs and gonadotrophs.

Kumari and Dutt (1990) indicated that the gonadotrophs of Puntius sarana attain maximum values (size and number) during the breeding season. In addition, Zohar et al. (2010) stated that the gonadotrophic cells of teleost fishes play critical roles in the regulation of reproductive processes, so the optimal rates of synthesis and secretion of gonadotrophic hormones are necessary for successful gonadal maturation 
and spawning. Furthermore, Chatterjee and Chakrabarti (2014) stated that the gonadotropic cells of Mystus vittatus form the major component of the proximal pars distalis and exhibit their prominence by having densely stained basophilic cytoplasm during the maturation and spawning phases of testes, while these cells are more or less inactive during the post-spawning phase.

Abou-Seedo and Al-Khatib (1995) stated that the fish species of the family Mugilidae (mullets) are considered as a major food source for the rapidly growing human population. So, they become desirable candidates for fish farming. Despite their economic importance, only limited information is available on their reproduction aspects. Moreover, Abou-Seedo and Dadzie (2004) stated that there is very limited and disparate information on all aspect of the biology and reproduction of L. carinata, in spite of its worldwide commercial importance.

So, the present research is undertaken to clarify the morphological and histological characters of the pituitary gland of the mature male and female $L$. carinata from the Suez Bay and possible seasonal variations of its cells during the reproductive cycle. Moreover, these data may help in the management of the reproductive process and future aquaculture studies of this species.

\section{MATERIALS AND METHODS}

\section{1- The animal:}

80 mature specimens of male and female Liza carinata (Valenciennes, 1836), ranging from 14-18 cm as a total length and 31-72 gm as a total body weight, were obtained alive from the gentle fishermen at the Suez Bay of the Red Sea seasonally during two successive years from January 2009 to January 2011.

\section{2- The morphological study:}

The specimens of $L$. carinata were dissected and the ovaries or testes were dissected free, removed out, blotted by a filter paper and the gonads were grossly examined and were placed in the proper stage of maturity, according to the size, shape and colour. Moreover, the brain and the attached pituitary gland of L. carinata were rapidly dissected out of the skull and photographed by the Sony digital camera.

\section{3- The histological study:}

The dissected brain with the attached pituitary gland of $L$. carinata was fixed immediately in a freshly prepared Zenker's formol solution for 24 hours. The materials were dehydrated in ethanol, cleared in the terpineol, embedded in parablast and then were sectioned. The 5-7 $\mu \mathrm{m}$ sections were stained with Heidenhain's azan, according to Rizkalla's modification (1970). These sections were carefully examined and photomicrographs were made.

\section{4- The ultrastructural studies:}

The whole pituitary gland of $L$. carinata was fixed in cold $3 \%$ glutaraldehyde solution in phosphate buffer ( $\mathrm{pH} \mathrm{7.4)}$ for 2 hours at $4^{\circ} \mathrm{C}$. The materials were then postfixed in $2 \%$ osmium tetraoxide $\left(\mathrm{OsO}_{4}\right)$ for one hour in a dark place at $4^{\circ} \mathrm{C}$. The materials were then dehydrated in an ascending ethanol series ten minutes each, at $4^{\circ} \mathrm{C}$. The materials were then cleared in propylene oxide and infiltrated with and embedded in epoxy resin at $60^{\circ} \mathrm{C}$.

Semithin sections $(1 \mu \mathrm{m}$ thick) were cut with the RMC-MT7 ultramicrotome and stained with toluidine blue. The semithin sections of the pituitary gland were then examined to select the suitable areas for ultrathin sectioning.

Ultrathin sections (600 $\mathrm{A}^{\circ}$ thick) were cut and stained with uranyl acetate and lead citrate according to Reynolds (1963). Finally, the sections were then examined 
with JOEL 1010 transmission electron microscope at the Regional Center for Mycology and Biotchnology, Al-Azhar University and at the National Cancer Institute, Cairo University.

\section{RESULTS}

\section{The morphological studies: -}

The gonads of the adult $L$. carinata are represented by a pair of elongated bodies which are located in the abdominal cavity. The size, shape, colour and diameter of the gonads differ according to the maturity stage of the fish during the different seasons of the year. The maturity stages of the gonads of $L$. carinata can be classified into the following three stages, namely: the post-spawning stage (from late December to late June), pre-spawning stage (from late June to late September) and spawning stage (from late September to late December) (Fig. 1).

Furthermore, the pituitary gland of $L$. carinata is whitish creamy in colour, it has an ovoid body with a long axis measuring about $1.25 \mathrm{~mm}$ (Fig. 2). The pituitary gland is devoid of a distinct hypophyseal stalk and is directly connected to the ventral side of the fore-brain.

\section{The histological studies:}

The pituitary gland of $L$. carinata is differentiated into two main divisions, the adenohypophysis and neurohypophysis. The former division is the glandular part, while the latter is the nervous part. The adenohypophysis is further subdivided into three glandular regions, namely: the pro-adenohypophysis, meso-adenohypophysis and meta-adenohypophysis. These glandular regions are arranged in a linear design and are easily distinguished from each other by their different staining affinities, but their boundaries are confluent and are not marked by septa of connective tissue. Moreover, the neurohypophysis is formed of a compact mass of nervous tissue which gives off processes that interdigitate into the adenohypophysis (Fig. 3).

\section{A- The adenohypophysis:}

\section{i- The pro-adenohypophysis:}

The pro-adenohypophysis (rostral pars distalis) occupies the most anterior region of the pituitary gland, (Fig. 3), and it is characterized by a high constituent of acidophils (A1) that aggregate to form masses separated by the neurohypophysial processes. Some of these cells are arranged in follicular structures which surround blood capillaries (Fig. 4).

The acidophils (A1) are stained red with the azan staining technique. They are rounded in shape, with large rounded and centrally located nuclei that have prominent centrally located nucleoli (Fig. 5). The diameter of these cells is about $5.5 \mu \mathrm{m}$, while the diameter of their nuclei is about $3.3 \mu \mathrm{m}$.

According to the staining affinity and location, the acidophils (A1) seem to be the lactotrophs which show no significant changes all the year round.

\section{ii- The meso-adenohypophysis:}

The meso-adenohypophysis (proximal pars distalis) occupies the middle region of the pituitary gland and lies posteriorly to the pro-adenohypophysis. Also, it continues ventrally and forms a thin layer that envelops completely the metaadenohypophysis. The meso-adenohypophysis contains two types of cells, namely: the acidophils and basophils (Fig. 3).

The acidophils (A2) are found mainly in the dorsal region and occasionally in the middle region of the meso-adenohypophysis (Fig. 3). These cells are stained deeply red with the azan technique. They are found in masses or in highly convoluted 
cords separated by vascular sheets of the neurohypophysial processes. The acidophils (A2) are rounded, ovoid or pyramidal cells with large eccentric nuclei and darkly stained secretory granules. The nuclei are rounded with prominent centrally located nucleoli (Fig. 6). The long axis of each cell is about $9 \mu \mathrm{m}$ and the diameter of the nucleus is about $3.6 \mu \mathrm{m}$.

According to the staining affinity and location, the acidophils (A2) seem to be the somatotrophs. The generalized picture of these cells shows no significant changes all the year round.

The basophils are the prevailing meso-adenohypophysial cell type and are divided into two types: the basophils (B1) and basophils (B2). The basophils (B1) are found in the middle region of the meso-adenohypophysis, while the basophils (B2) are found in the peripheral zone of the meso-adenohypophysis (Fig. 7).

The basophils (B1) are oval, pyramidal or polygonal in shape with large eccentric nuclei (their diameter is about $3.3 \mu \mathrm{m}$ ) that possess prominent centrally located nucleoli (Fig. 8). The basophils (B1) show pronounced seasonal variations and their cytoplasm shows different stages of granulation and vacuolation.

In the post-spawning season, the basophils (B1) show a weak staining affinity or appear as if they are negatively stained by the azan staining technique. These cells show degranulated and vacuolated cytoplasm (Figs. 7 and 8). The long axes of these cells are about $7.8 \mu \mathrm{m}$. On the other hand, during the pre-spawning season, the basophils (B1) are stained uniformly deep blue; some cells still are faintly stained due to revival of their granular contents (Fig. 9). The long axes of these cells are about 8.9 $\mu \mathrm{m}$. Moreover, during the spawning season, the basophils (B1) are uniformly stained blue and are increased in size with the long axes measuring about $10 \mu \mathrm{m}$ (Fig. 10).

The basophils (B2) are rounded in shape and possess rounded and centrally located nuclei (Fig. 11). The diameter of these cells is about $5 \mu \mathrm{m}$ and the diameter of their nuclei is about $3.2 \mu \mathrm{m}$. The basophils (B2) show no significant seasonal variations.

According to the staining affinity and location, the basophils (B1) and basophils (B2) seem to be the gonadotrophs and thyrotrophs, respectively.

\section{iii- The meta-adenohypophysis:}

The meta-adenohypophysis (pars intermedia) occupies the posterior part of the pituitary gland and appears as a convoluted epithelial sac which encloses the neurohypophysis that forms the main core (Figs. 3 and 12). The metaadenohypophysis consists of the amphiphils (Ml) that are found near the neurohypophysis (Fig. 12). These cells are rounded in shape and have rounded centrally located nuclei and faintly stained cytoplasm (Fig. 13). The diameter of these cells is about $5.3 \mu \mathrm{m}$ and the diameter of their nuclei is about $3.3 \mu \mathrm{m}$.

According to the staining affinity and location, the amphiphils seem to be the melanotrophs. No apparent seasonal variations are displayed by the metaadenohypophysial cells.

\section{B- The neurohypophysis:}

The neurohypophysis (pars nervosa) consists of the nervous tissue that extends ventrally and gives off a few and short processes which penetrate the pro- and mesoadenohypophyses, and it forms a central core of the meta-adenohypophysis (Fig. 3).

In contrast with the glandular adenohypophysis, the neurohypophysis consists mainly of nerve fibres and contains, especially near the meta-adenohypophysial region, variable amounts of neurosecretory granules (Fig. 14) which may be regarded as constituting the hormonal secretory product of the hypothalamic neurosecretory system. These neurosecretory granules can be detected in a considerable amount 
during the pre-spawning and spawning seasons (Figs. 14 and 15), but they are rarely seen in the post-spawning season (Fig. 12).

\section{The ultrastructural studies:}

In the pituitary gland of $L$. carinata, there are no apparent seasonal changes in any cell types, except the basophils (B1) (the gonadotrophs) of the mesoadenohypophysis. Therefore, these cells are studied ultrastructurally. The seasonal variations of the basophils (B1) are divided into three phases, namely: the postspawning, pre-spawning and spawning phases.

During the post-spawning phase, many of the basophils (B1) contain prominent and numerous vacuoles of various size that occupying the most of the cytoplasm (Fig. 16). Furthermore, most of these vacuoles contain fibrillar inclusions. In addition, there are few and small secretory granules with variable electron density (Fig. 17). The diameter of these granules is about $200 \mathrm{~nm}$. Moreover, the cytoplasm contains rounded nucleus (Fig. 16), mitochondria with few cristae and the Golgi apparatus (Fig. 17).

During the pre-spawning phase, the basophils (B1) possess numerous and large secretory granules (Fig. 18), with a diameter of about $300 \mathrm{~nm}$. The endoplasmic reticulum is either found as long strands that surround the nucleus, (Fig. 19), or as numerous wide cisternae that are scattered throughout the cell cytoplasm (Fig. 18). The small rounded mitochondria are abundant, scattered throughout the cytoplasm and have dense matrix. In addition, the Golgi apparatus lies near the nucleus and consists of few flattened cisternae (Fig. 20).

During the spawning phase, the basophils (B1) retain the general appearance of the previous phase, but the secretory granules become more numerous and larger. The diameter of these secretory granules is about $370 \mathrm{~nm}$. There are also numerous wide cisternae of endoplasmic reticulum, (Fig. 21), the Golgi apparatus that lies near the nucleus, and rounded mitochondria that are found between the secretory granules (Fig. 22).

\section{DISCUSSION}

The pituitary gland of $L$. carinata is a whitish creamy ovoid body that is directly connected to the ventral side of the fore-brain without a distinct hypophyseal stalk. According to the variations exiting in the manner of attachment of the pituitary gland to the brain, the pituitary gland $L$. carinata is of the platybasic type. These results agree with those of Singh and Sathyanesan (1962) in Ophicephalus punctatus, Rizkalla (1976) in Mugil auratus and Baskaran (1991) in Liza parsia. Moreover, the leptobasic type of the pituitary gland (the pituitary gland is attached to the fore-brain by a distinct hypophyseal stalk) was described by Jafri and Ensor (1980) in Rutilus rutilus, Kumari and Dutt (1990) in Puntius sarana, Cinquetti and Dramis (2006) in Padogobius martensi and Honji et al. (2013) in Salminus hilarii.

The pituitary gland of $L$. carinata, as in most teleosts, is differentiated into two main divisions, namely: the glandular adenohypophysis and the nervous neurohypophysis. Moreover, the adenohypophysis is further subdivided into three glandular regions, namely: the pro-adenohypophysis, meso-adenohypophysis and meta-adenohypophysis situated in an antero-posterior arrangement. These glandular regions are easily distinguished from each other by their different staining affinities, but their boundaries are confluent and not marked by septa of connective tissue. These results are in agreement with those obtained by Gaber (2000) in Bagrus docmac and 
Bagrus bayad, El-Zoghby et al. (2008) in Clarias lazera and El-Sakhawy et al. (2011) in Oreochromis niloticus.

The pro-adenohypophysis of $L$. carinata occupies the most anterior region of the pituitary gland and is characterized by a high constituent of acidophils (A1), the lactotrophs, that aggregate to form masses separated by the neurohypophysial processes. The predominance of acidophils in the pro-adenohypophysis was also reported in Oncorhynchus sp. (Robertson and Wexler, 1962) and in Lates niloticus, Chrysichthys auratus, Malapterurus electricus and Hydrocyon forskalii (El-Dossoky, 1985). Moreover, in the present study, the acidophils (A1) of the proadenohypophysis show no significant seasonal change. This current result is in agreement with that recorded by Moitra and Sarkar (1976) in Cirrhinus mrigala, Ramadan et al. (1988) in Sparus aurata and Honji et al. (2013) in Salminus hilarii.

The meso-adenohypophysis of $L$. carinata occupies the middle region of the pituitary gland and contains two types of cells, namely: the acidophils and basophils. The aforementioned observations agree with that of El-Dawi (1990) and Kharat and Khillare (2013) in Schilbe mystus and Nemacheilus mooreh, respectively. The acidophils (A2) of L. carinata are found mainly in the dorsal region and occasionally in middle region of the meso-adenohypophysis, while the basophils (B1) are found in the middle region of the meso-adenohypophysis and the basophils (B2) are found in the peripheral zone of the meso-adenohypophysis. These results are in accordance with those of Lehri (1966) in Clarias batrachus, Rizkalla (1976) in Mugil auratus, and Ramadan et al. (1988) in Sparus aurata.

In $L$. carinata, the restriction of the acidophils (A2) to the dorsal region of meso-adenohypophysis as multicellular layers bordering the neurohypophysial processes also recorded by El-Gohary (2001) in Oreochromis niloticus, Sanchez Cala et al. (2003) in Trachinus draco and Ekici and Timiur (2013) in Cyprinus carpio. According to the staining affinity and location, the acidophils (A2) in the mesoadenohypophysis of L. carinata seem to be the somatotrophs. A similar result was recorded in Pomatoschistus microps (Ho-Shih, 1979), in Sparus aurata (Ramadan et al., 1987) and in Padogobius martensi (Cinquetti and Dramis, 2006). The generalized picture of the acidophils (A2) of L. carinata shows no significant changes all the year round. The aforementioned result is in agreement with that recorded by Scruggs (1951) in Cyprinus carpio and Carassius auratus and Bisht (1975) in Schizothorax richardsonii and Ramadan et al. (1988) in Sparus aurata.

In $L$. carinata, the basophils are the prevailing meso-adenohypophysial cell type and are distinguished into two types: the basophils (B1), gonadotrophs, and basophils (B2), thyrotrophs. Similar observations were recorded by Sathyanesan (1960) in Mystus seenghala and Barbus stigma, Van Oordt et al. (1987) in Clarias gariepinus and Honji et al. (2013) in Salminus hilarii.

The basophils (B1) of L. carinata show pronounced seasonal variations that run parallel with those in gonads. In addition, during the post-spawning season, the basophils (B1) show a heavy degranulation and a weak affinity or negative staining ability on account of the discharge of their secretory granules. On the other hand, these cells in the pre-spawning season are characterized by restitution of the secretory granules. Moreover, during the spawning season, these cells become heavily loaded with the secretory granules. These findings are in agreement with those reported in Puntius sarana (Kumari and Dutt, 1990), in Oreochromis niloticus (El-Sakhawy et al., 2011) and in Nemacheilus mooreh (Kharat and Khillare, 2013).

In $L$. carinata, the ultrastructure of the basophils (B1), the gonadotrophs, is generally characterized by the presence of secretory granules, endoplasmic reticulum, 
mitochondria and Golgi apparatus. Moreover, the most striking feature of the basophils (B1), during different reproductive seasons, is the number and size of the secretory granules. These secretory granules are few in number and small in size in the post-spawning season, while they become numerous and larger in both prespawning and spawning seasons. These results are in accordance with those of Peute et al. (1978) in Salmo gairdneri, Ueda and Takahashi, (1980) and Ueda (1981) in Misgurnus anguillicaudatus and Young and Ball (1982) in Poecilia latipinna. Furthermore, during the post-spawning season, the basophils (B1) of L. carinata are characterized by the presence of numerous vacuoles that containing fibrillar inclusions. The aforementioned observation is also described by Bage et al. (1974) in Leuciscus rutilus. In addtion, Parhar et al. (1998) suggested that these vacuoles of the gonadotrophic cells of Thalassoma duperrey are formed by coalesced cisternae of endoplasmic reticulum.

The meta-adenohypophysis of L. carinata occupies the posterior part of gland and appears as a convoluted epithelial sac which encloses the bulk of neurohypophysis. Moreover, the meta-adenohypophysis consists of the amphiphils (Ml), the melanotrophs. Similar observations were reported by Rizkalla and Yoakim (1975) in Synodontis schall. On the other hand, Benjamin (1979) and El-Sakhawy et al. (2011) reported that the meta-adenohypophysis of Crenilabrus melops and Oreochromis niloticus, respectively, is formed mainly of two amphiphilic cell types, namely: melanotrophs and somatolactotrophs. In addition, no apparent seasonal variations are displayed by the meta-adenohypophysial cells of $L$. carinata. Similar result was reported in S. schall (Rizkalla and Yoakim, 1975), in Ictalurus punctatus (Massoud, 1982) and in O. niloticus (El-Sakhawy et al., 2011).

The neurohypophysis of $L$. carinata is formed of a compact mass of nervous tissue which gives off processes that ramify into all the three regions of the adenohypophysis, especially the meta-adenohypophysis which receives the richest ramifications. These results are in agreement with those of Honji et al. (2013) in Salminus hilarii and Grandi et al. (2014) in Ctenophargngodon idella. But, these results disagree with those of Scruggs (1939) who reported that the neurohypophyseal ramifications of Pseudopleuronectes sp. are confined to the meta-adenohypophysis.

In $L$. carinata, the neurohypophysis contains, especially near the metaadenohypophyseal region, variable amounts of neurosecretory granules which may be regarded as constituting the hormonal secretory product of the hypothalamic neurosecretory system. Similar findings were recorded by Kamel et al. (1973) in Chrysichthys auratus, Rizkalla and Yoakim (1975) in Synodontis schall and Massoud (1982) in Ictalurus punctatus. Moreover, the neurosecretory granules of L. carinata can be detected in a considerable amount during the pre-spawning and spawning seasons, but they are rarely seen in the post-spawning one. Similar observations are seen in Carassius auratus (Scruggs, 1951) and S. schall (Yoakim, 1971). In addition, Ramadan et al. (1988) suggested that these neurosecretory granules of Sparus aurata may be involved in the reproductive process.

\section{REFERENCES}

Abou-Seedo, F. S. and Al-Khatib, H. Y. (1995). A histological and macroscopic study of ovarian development in the grey mullet, Liza carinata, (Valenciennes 1836). J. Univ. Kuwait (Sci.), 22: 239-354. 
Abou-Seedo, F. S. and Dadzie, S. (2004). Reproductive cycle in the male and female grey mullet, Liza klunzingeri, in the Kuwaiti waters of the Arabian Gulf. Cybium, 28(2): 97-104.

Bage, G.; Ekengren, B.; Fernholm, B. and Fridberg, G. (1974). The pituitary gland of the roach, Leuciscus rutilus. II- The proximal pars distalis and its innervations. Acta Zool., 55: 191-204.

Baskaran, G. (1991). Studies on the hypothalamo-hypophysial neurosecretory complex and the pituitary of some teleostean fishes. Ph.D. thesis, J. C. Bose School of Life Science, Pondicherry University, India.

Benjamin, M. (1979). The cell types in the adenohypophysis of the marine teleost (Crenilabrus melops). Acta Zool., 60: 105-113.

Bisht, J. S. (1975). Cyclic changes in the pituitary gland in correlation with the testicular cycle in a hill stream teleost, Schizothorax richardsonii (Gray and Hard). Acta Anat., 92(3): 443 - 453.

Chatterjee, N. and Chakrabarti, P. (2014). Distributional pattern of different cells with special emphasis on the seasonal variations of gonadotrophs in the pituitary gland of Mystus vittatus (Bloch, 1794) in relation to testicular activities. Int. J. Fish. Aquat. Stud., 2(1): 79-87.

Cinquetti, R. and Dramis, L. (2006). Identification and localization of hormoneproducing cells in the pituitary of male Padogobius martensi (Pisces, Gobiidae): a histochemical and immunocytochemical study. J. Fish Biol., 68 (B): 235-250.

de Jesus, L. W. O.; Chehade, C.; Costa, F. G. and Borella, M. I. (2014). Pituitary gland morphogenesis and ontogeny of adenohypophysial cells of Salminus brasiliensis (Teleostei, Characiformes). Fish Physiol. Biochem., 40: 897-909.

Ekici, A. and Timiur, M. (2013). An anatomical and histochemical examination of the pituitary gland of carp (Cyprinus carpio). Turk. J. Vet. Anim. Sci., 37: 399-403.

El-Dawi, F. (1990). Studies on the hypothalamo-hypophysial complex in correlation with the ovarian cycle of a certain Teleost. Ph.D. thesis, Faculty of Science, Ain Shams University, Egypt.

El-Dossoky, N. I. (1985). Morphological and histological study on the pituitary gland in some teleost species. M. Sc. thesis, Faculty of Science, Tanta University, Egypt.

El-Gohary, N. M. A. (2001). The effect of water quality on the reproductive biology of the Nile tilapia, Oreochromis niloticus in Lake Manzalah. Ph.D. thesis. Faculty of Science. Ain Shams University, Egypt.

El-Sakhawy, M. A.; El-Shammaa, M. A.; Abd Rabou, M. I.; El-Saba, A. A. and Hussein, S. H. (2011). Seasonal histology and histochemistry of the adenohypophysis of Nile Tilapia (Oreochromis niloticus). J. Vet. Anat., 4 (2): 39-60.

El-Zoghby, I. M. A.; Bakry, H. H.; Ghallab, A. M. and Emam, M. A. (2008). Histological studies on the pituitary gland of catfish (Clarias lazera) during different seasons. $32^{\text {nd }}$ Sci. Conf. Egyp. Soc. Hist. Cyto., pp.24-35.

Gaber, S. A. O. (2000). Biological, histological and histochemical studies on the reproductive organs and pituitary gland of Bagrus docmac and Bagrus bayad in the Nile water, with special reference to the ultrastructure of supporting tissues. Ph.D. thesis, Faculty of Science, Zagazig University, Egypt.

Grandi, G.; Marchetti, M. G.; Lanzoni, M. and Chicca, M. (2014). Immunocytochemical and ultrastructural identification of adenohypophysial cells in Ctenopharyngodon idella (Cypriniformes: Cyprinidae) during gonadal differentiation. Fish Physiol. Biochem., 40: 1115-1139. 
Honji, R. M.; Nóbrega, R. H.; Pandolfi, M.; Shimizu, A.; Borella, M. I. and Moreira, R. G. (2013). Immunohistochemical study of pituitary cells in wild and captive Salminus hilarii (Characiformes: Characidae) females during the annual reproductive cycle. SpringerPlus, 2:460-474.

Ho-Shih, S. (1979). Pituitary structure and cycles of the common goby, Pomatoschistus microps (Teleostei, Gobiidae). Ph. D. thesis, Bristol University, U. S. A.

Jafri, S. I. H. and Ensor, D. M. (1980). Cell types in the pituitary of the roach, Rutilus rutilus (L.), (Teleostei). J. Anat., 130(4): 667-672.

Jose, T. M. and Sathyanesan, A. G. (1977). Pituitary cytology of the Indian carp, Labeo rohita (Ham.). Anat. Anz., 142: 410-423.

Kamel, A.; Rizkalla, W. and Shakhsheir, E. (1973). The pituitary gland of the Nile teleost fish, Chrysichthys auratus (Geoffr.). Proc. $7^{\text {th }}$ Arab Sci. Conger., 4: 8799.

Khan, H. (1962). The functional anatomy of the pituitary of a freshwater teleost, Labeo rohita (Ham.). Proc. Nat. Acad. Sci. Ind., 32: 101-108.

Kharat, S. S. and Khillare, Y. K. (2013). Morphology and histology of pituitary gland of torrential stream fish, Nemacheilus mooreh (Sykes). Int. J. Bioassays, 2 (8): 1079-1084.

Kumari, M. and Dutt, N. H. (1990). Cyclical changes in the pituitary gonadotrophs (GTH cells) in relation to the testicular cycle in Puntius sarana (Hamilton). Folia Morphol., 38(2): 118-127.

Lehri, G. K. (1966). The pituitary gland of a catfish, Clarias batrachus. Copeia, 4: 810-818.

Massoud, A. A. (1982). Seasonal histochemical changes in the pituitary gland of channel catfish, Ictalurus punctatus (Rafinesque).Ph.D. thesis, Memphis State University, U.S.A.

Moitra, S. K. and Sarkar, S. K. (1976). Seasonal variations in the histology of the pituitary gland of Cirrhinus mrigala (Ham.) an Indian Freshwater major carp in relation to gonadal activity. Z. Mikrosk. Anat. Forsch., 90(1): 154-74.

Munro, A. D. (1985). The structure of the adenohypophysis of Aequidens pulcher (Teleostei, Cichlidae). I- Histolgical and immunohistochemical studies. Gen. Comp. Endocrinol., 60 (2): 215-226.

Narayan, A.; George, K. C. and Diwan, A. D. (1985). Histology of the pituitary gland of the grey mullet, Mugil cephalus L. Fish Biol., 26 (4): 381- 390.

Parhar, I. S.; Nagahama, Y.; Grau, E. G. and Ross, R. M. (1998). Immunocytochemical and ultrastructural identification of pituitary cell types in the protogynous Thalassoma duperrey during adult sexual ontogeny. Zool. Sci., 15: 263-276.

Peute, J.; Goos, H. J. Th.; de Bruyn, M. G. A. and Van Oordt, P. G. W. J. (1978). Gonadotropic cells of the rainbow trout pituitary during the annual cycle. Ultrastructure and hormone content. Ann. Biol. Anim. Biochem. Biophys., 18(4): 905-910.

Pickford, G. E. and Atz, J. W. (1957). The Physiology of the Pituitary Gland of Fishes. $1^{\text {st }}$ edition. Zoological Society, New York.

Ramadan, A. A.; Ezzat, A. A.; Meguid, N.A.; Khadre, S. E. M. and Abdel-Aziz, S. H. (1987). Seasonal changes in the cytology and cytochemistry of the pituitary gland of Sparus aurata. Folia Morphol., 35: 274-282. 
Ramadan, A. A.; Ezzat, A. A.; Khadre, S. E. M.; Meguid, N. A. and Abdel-Aziz, S. H. (1988). Cyclic histological changes in the pituitary gland of the Sparus aurata in correlation to the gonadal cycle. Folia Morphol., 36: 113-124.

Reynolds, E. S. (1963). The use of lead citrate at high $\mathrm{pH}$ as an electron opaque stain in electron microscopy. J. Cell Biol., 17: 208-212.

Rizkalla, W. 1970. A differential staining technique for the epithelial cells of the islets of Langerhans and the adenohypophysis. Ain Shams Sci. Bull., 14: 185-190.

Rizkalla, W. (1976). The hypophysis of the marine teleost fish, Mugil auratus Risso. Acta Biol. Acad. Sci. Hung., 27(2-3): 155-162.

Rizkalla, W. and Yoakim, E. G. (1975). Seasonal changes in the pituitary gland of the Nile catfish, Synodontis schall (Bloch-Schneider). Lib. J. Sci., (5): 15-29.

Robertson, O. H. and Wexler, B. C. (1962). Histological changes in the pituitary gland of the Pacific salmon (genus Oncorhynchus) accompanying sexual maturation and spawning. J. Morphol., 110(2):176- 185.

Sahai, S. (1984). Adenohypophyseal cell types in the pituitary gland of Osteobrama cotio (Ham.). Folia Morphol., 32(3): 279-284.

Sanchez Cala, F.; Portillo, A.; Martin del Rio, M. P. and Mancera, J. M. (2003). Immunocytochemical characterization of adenohypophyseal cells in the greater weever fish (Trachinus draco). Tiss. Cell, 35(3): 169-178.

Sathyanesan, A. G. (1960). Correlative cyclical changes in the pituitary and gonads of Mystus seenghala, (Sykes) and Barbus stigma (Cuv and Val.). J. Zool. Soc., 12 (2): 175-190.

Scruggs, W. M. (1939). The epithelial components of the teleost pituitary gland as identified by a standardized method of selective staining. J. Morphol., 65(2): 187-213.

Scruggs, W. M. (1951). The epithelial components and their seasonal changes in the pituitary gland of the carp (Cyprinus carpio, L.) and goldfish (Carassius auratus, L.). J. Morphol., 88: 441-470.

Singh, T. and Sathyanesan, A. G. (1962). A comparative study of the pituitary of some fresh-water fishes, with special reference to their histology. Proc. Zool. Soc. Ind., 15: 171-183.

Ueda, H. (1981). Changes of two types of pituitary gonadotrophs of the loach, Misgurnus anguillicaudatus, during gonadal development and reproductive cycle. Bull. Fac. Fish Hokkaido University, 32(2): 120-135.

Ueda, H. and Takahashi, H. (1980). Responses of two different types of pituitary gonadotrophs of the loach, Misgurnus anguillicaudatus, to gonadectomy and to exogenous sex steroids. Gen. Comp. Endocrinol., 40: 463-472.

Van Oordt, P. G. W. J.; Peute, J.; Van Den Hurk, R. and Viveen, W. J. A. R. (1987). Annual correlative changes in gonads and pituitary gonadotropes of Feral African Catfish, Clarias gariepinus. J. Aquacul., 63: 27-41.

Yoakim, E. G. (1971). Seasonal variations in the pituitary gland and gonads of the Nile catfish (Synodontis schall) in relation to its reproductive cycle. Ph.D. thesis, Faculty of Science, Ain Shams University, Egypt.

Young, G. and Ball, J. N. (1982). Ultrastructural changes in the adenohypophysis during the ovarian cycle of the viviparous teleost, Poecilia latipinna. I- The gonadotrophic cells. Gen. Comp. Endocrinol., 48(1): 39-59.

Zohar, Y.; Munoz-Cueto, J. A.; Elizur, A. and Kah, O. (2010). Neuroendocrinology of reproduction in teleost fish. Gen. Comp. Endocrinol., 165(3): 438-455. 


\section{EXPLANATION OF FIGURES}

Fig. 1: photographs of dissected adult males and females L. carinata, showing the morphological features of the testes and ovaries, respectively, during the different reproductive seasons; $\mathrm{A}$ and $\mathrm{B}$ : the post-spawning season, $\mathrm{C}$ and $\mathrm{D}$ : the prespawning season and $\mathrm{E}$ and $\mathrm{F}$ : the spawning season.

Fig. 2: Photograph of the pituitary gland of $L$. carinata, showing its location.

Fig. 3: Photomicrograph of a sagittal section of the pituitary gland of $L$. carinata in the post-spawning season, showing the neurohypophysis and adenohypophysis which is differentiated into the pro-adenohypophysis, meso-adenohypophysis and metaadenohypophysis, acidophils (A2) and basophils (B1 and B2). (Azan stain).

Fig. 4: Photomicrograph of a sagittal section of the pituitary gland of $L$. carinata in the post-spawning season, showing the pro-adenohypophysis, acidophils (A1), neurohypophysial process and blood capillaries. (Azan stain).

Fig. 5: Photomicrograph of a sagittal section of the pituitary gland of $L$. carinata in the post-spawning season, showing the pro-adenohypophysis and acidophils (A1). (Azan stain).

Fig. 6: Photomicrograph of a sagittal section of the pituitary gland of $L$. carinata in the post-spawning season, showing the meso-adenohypophysis, acidophils (A2), secretory granules and neurohypophysial process. (Azan stain).

Fig. 7. Photomicrograph of a sagittal section of the pituitary gland of L. carinata in the post-spawning season, showing the meso-adenohypophysis, acidophils (A2) and basophils (B1 and B2). (Azan stain).

Fig. 8: Photomicrograph of a sagittal section of the pituitary gland of $L$. carinata in the post-spawning season, showing the meso-adenohypophysis, acidophils (A2), and basophils (B1). (Azan stain).

Fig. 9: Photomicrograph of a sagittal section of the pituitary gland of $L$. carinata in the pre-spawning season, showing the meso-adenohypophysis and basophils (B1). (Azan stain).

Fig. 10: Photomicrograph of a sagittal section of the pituitary gland of $L$. carinata in the spawning season, showing the meso-adenohypophysis and basophils (B1). (Azan stain).

Fig. 11: Photomicrograph of a sagittal section of the pituitary gland of $L$. carinata in the post- spawning season, showing the meso-adenohypophysis and basophils (B2). (Azan stain).

Fig. 12: Photomicrograph of a sagittal section of the pituitary gland of L. carinata in the post-spawning season, showing the meta-adenohypophysis, mesoadenohypophysis, neurohypophysis and amphiphils (Ml). (Azan stain).

Fig. 13: Photomicrograph of a sagittal section of the pituitary gland of $L$. carinata in the post-spawning season, showing the meta-adenohypophysis, neurohypophysis and amphiphils (Ml). (Azan stain).

Fig. 14: Photomicrograph of a sagittal section of the pituitary gland of $L$. carinata in the pre-spawning season, showing the meta-adenohypophysis, neurohypophysis and neurosecretory granules. (Azan stain).

Fig. 15: Photomicrograph of a sagittal section of the pituitary gland of $L$. carinata in the spawning season, showing the meta-adenohypophysis, neurohypophysis and neurosecretory granules. (Azan stain).

Fig. 16: Electron micrograph of the pituitary gland of $L$. carinata in the post- spawning season, showing the basophils (B1) with numerous vacuoles, few secretory granules and nucleus. 
Fig. 17: Electron micrograph of the pituitary gland of $L$. carinata in the post-spawning season, showing the basophils (B1) with the vacuoles containing fibrillar inclusions (arrow heads), mitochondria and Golgi apparatus.

Fig. 18: Electron micrograph of the pituitary gland of $L$. carinata in the pre-spawning season, showing the basophils (B1) with nucleus, secretory granules and endoplasmic reticulum.

Fig. 19: Electron micrograph of the pituitary gland of $L$. carinata in the pre-spawning season, showing the basophils (B1) with secretory granules and endoplasmic reticulum.

Fig. 20: Electron micrograph of the pituitary gland of $L$. carinata in the pre-spawning season, showing the basophils (B1) secretory granules, nucleus, endoplasmic reticulum, mitochondria and Golgi apparatus.

Fig. 21: Electron micrograph of the pituitary gland of L. carinata in the spawning season, showing the basophils (B1) with secretory granules and endoplasmic reticulum.

Fig. 22: Electron micrograph of the pituitary gland of $L$. carinata in the spawning season, showing the basophils (B1) with the secretory granules, nucleus, Golgi apparatus and mitochondria.

\section{ABBREVIATIONS LIST OF}

$\begin{array}{ll}\text { A1 } & \text { Acidophils (A1). } \\ \text { A2 } & \text { Acidophils (A2). } \\ \text { Ad } & \text { Adenohypophysis. } \\ \text { B1 } & \text { Basophils (B1). } \\ \text { B2 } & \text { Basophils (B2). } \\ \text { B1.cap } & \text { Blood capillary. } \\ \text { En.r } & \text { Endoplasmic reticulum. } \\ \text { G.ap } & \text { Golgi apparatus. } \\ \text { M } & \text { Mitochondria. } \\ \text { Me.ad } & \text { Meso-adenohypophysis. } \\ \text { Ml } & \text { Amphiphils (Ml). } \\ \text { Mt.ad } & \text { Meta-adenohypophysis. } \\ \text { N } & \text { Nucleus. } \\ \text { Ne.gr } & \text { Neurosecretory granules. } \\ \text { Neh } & \text { Neurohypophysis. } \\ \text { Neh.prs } & \text { Neurohypophysial processes. } \\ \text { Nu } & \text { Nucleolus. } \\ \text { Ov } & \text { Ovaries. } \\ \text { Pit.gd } & \text { Pituitary gland. } \\ \text { Pro.ad } & \text { Pro- adenohypophysis. } \\ \text { Scr.gr } & \text { Secretory granules. } \\ \text { Ts } & \text { Testes. } \\ \text { V } & \text { Vacuoles. }\end{array}$




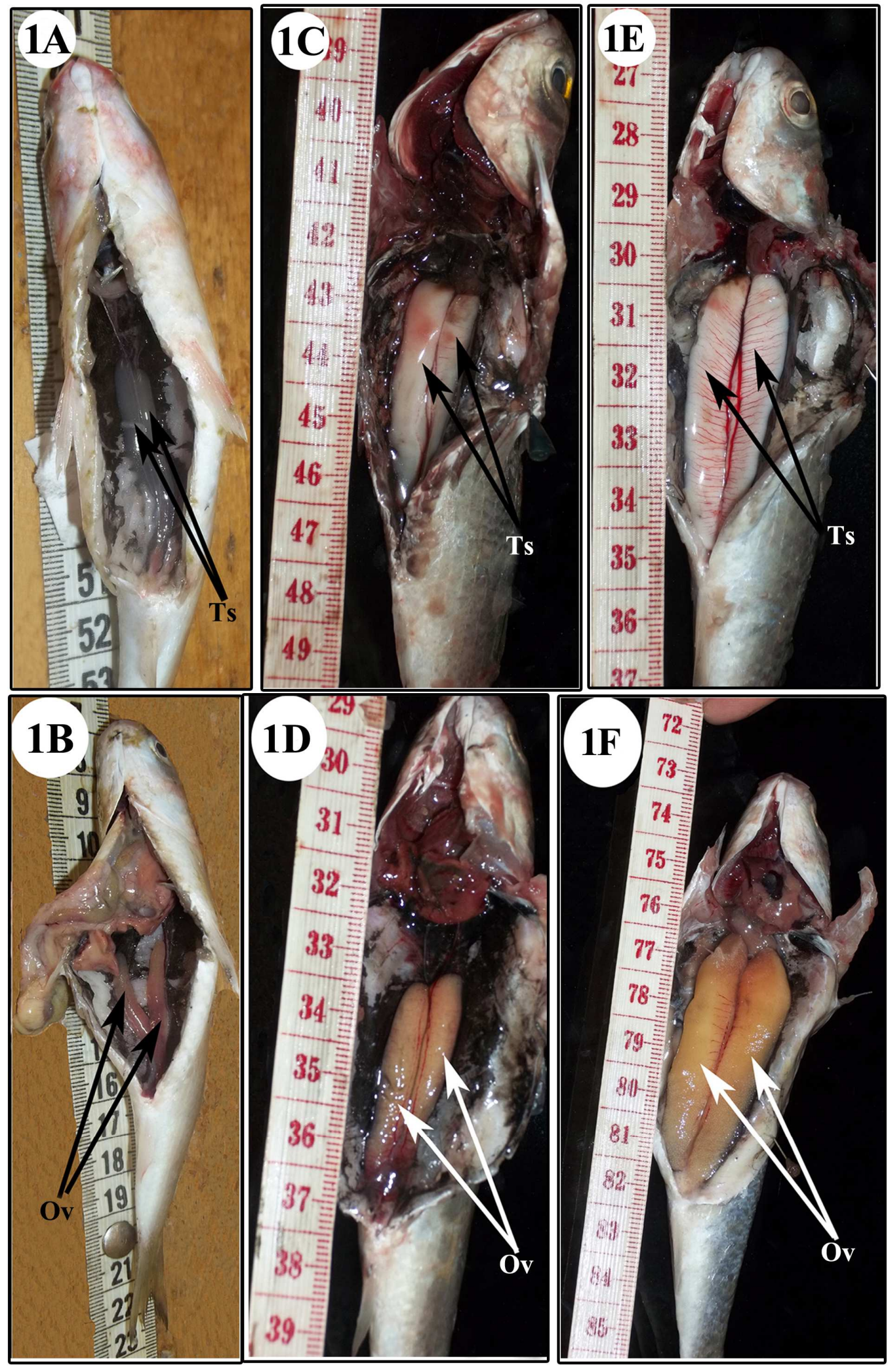



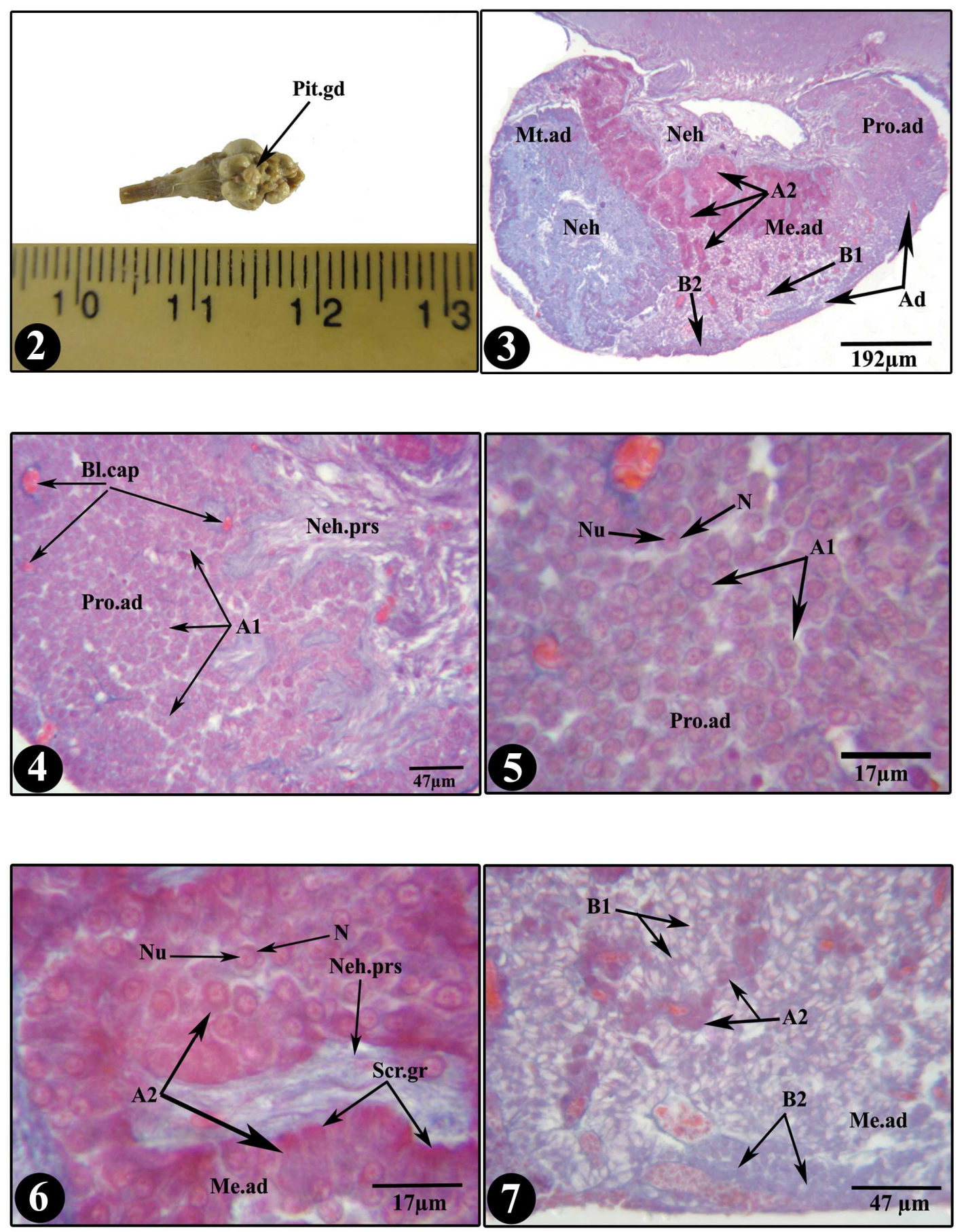

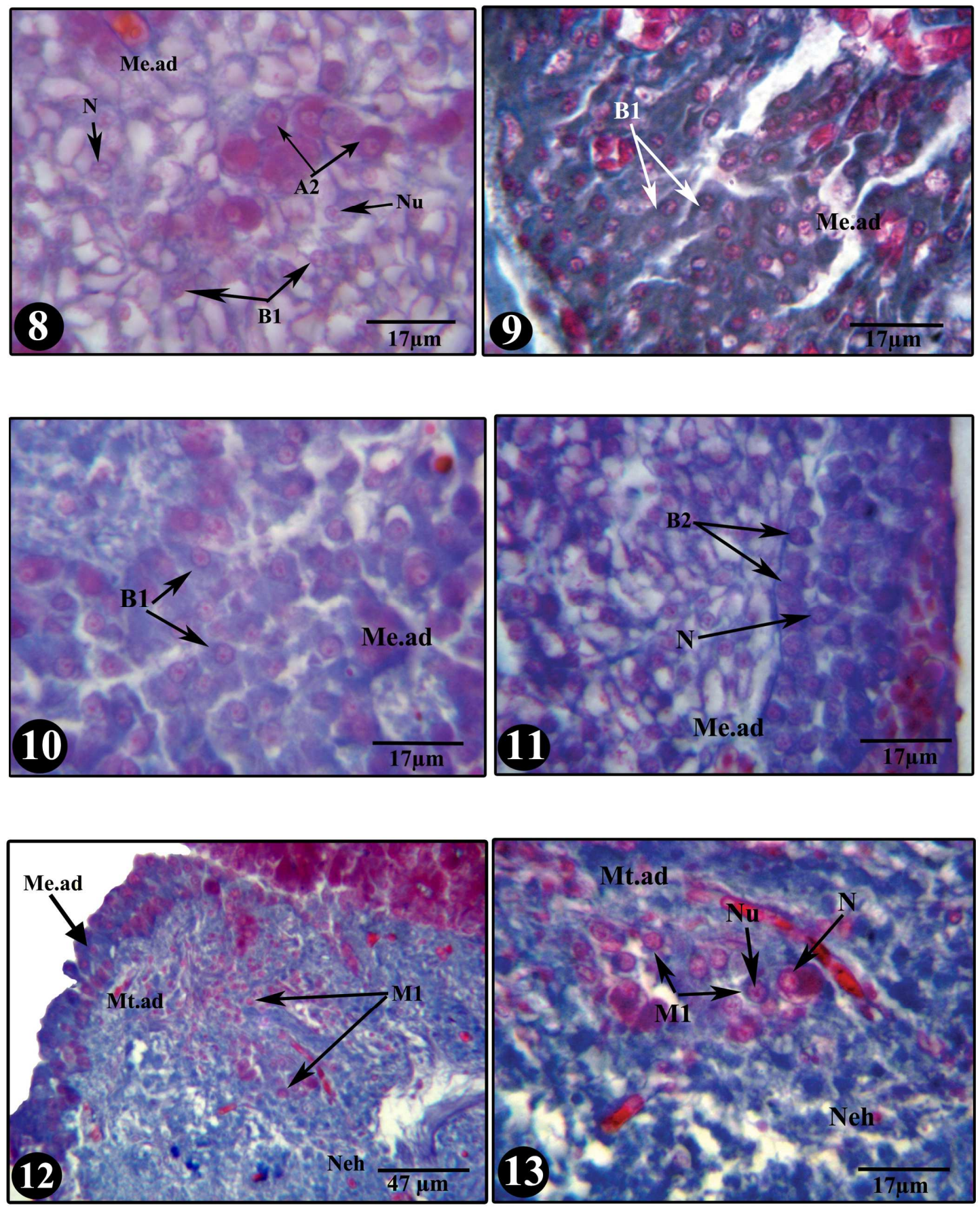

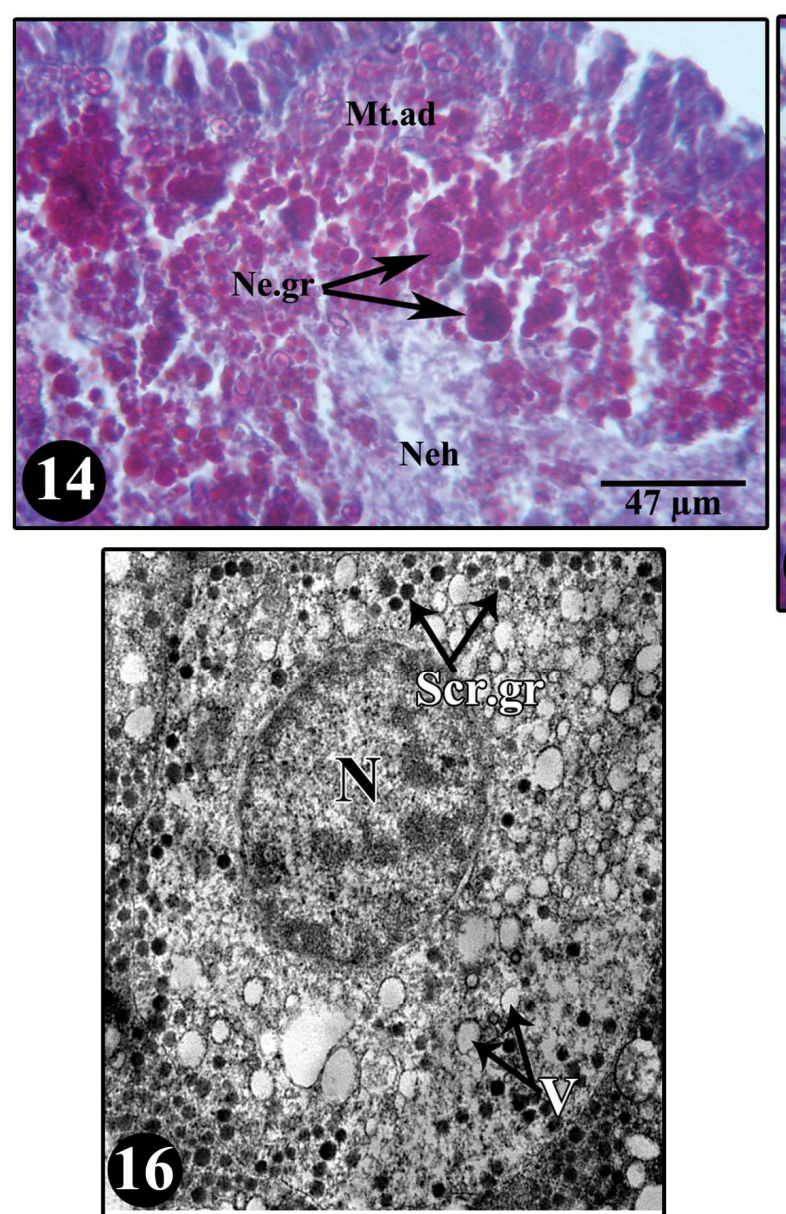

$500 \mathrm{~nm}$
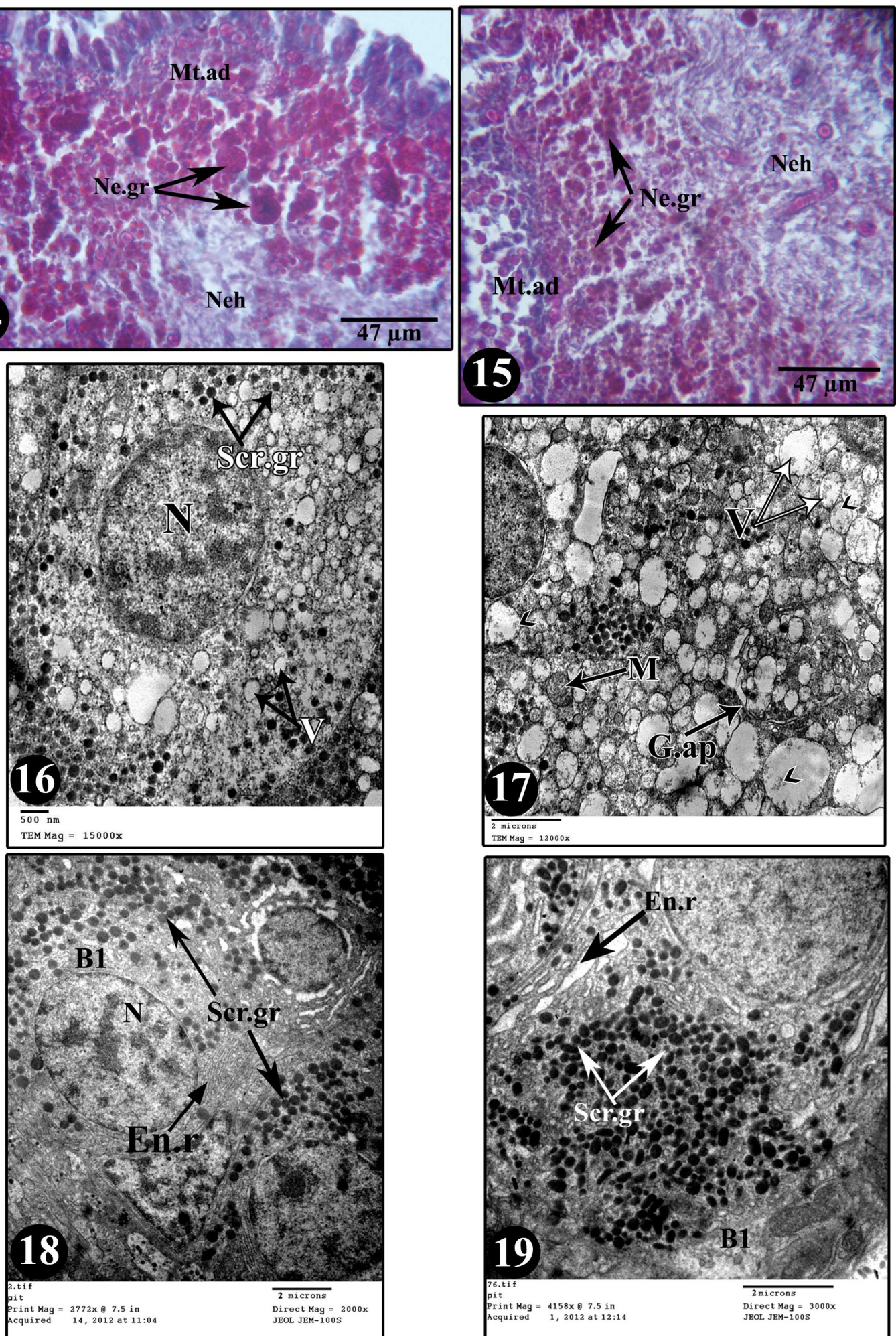

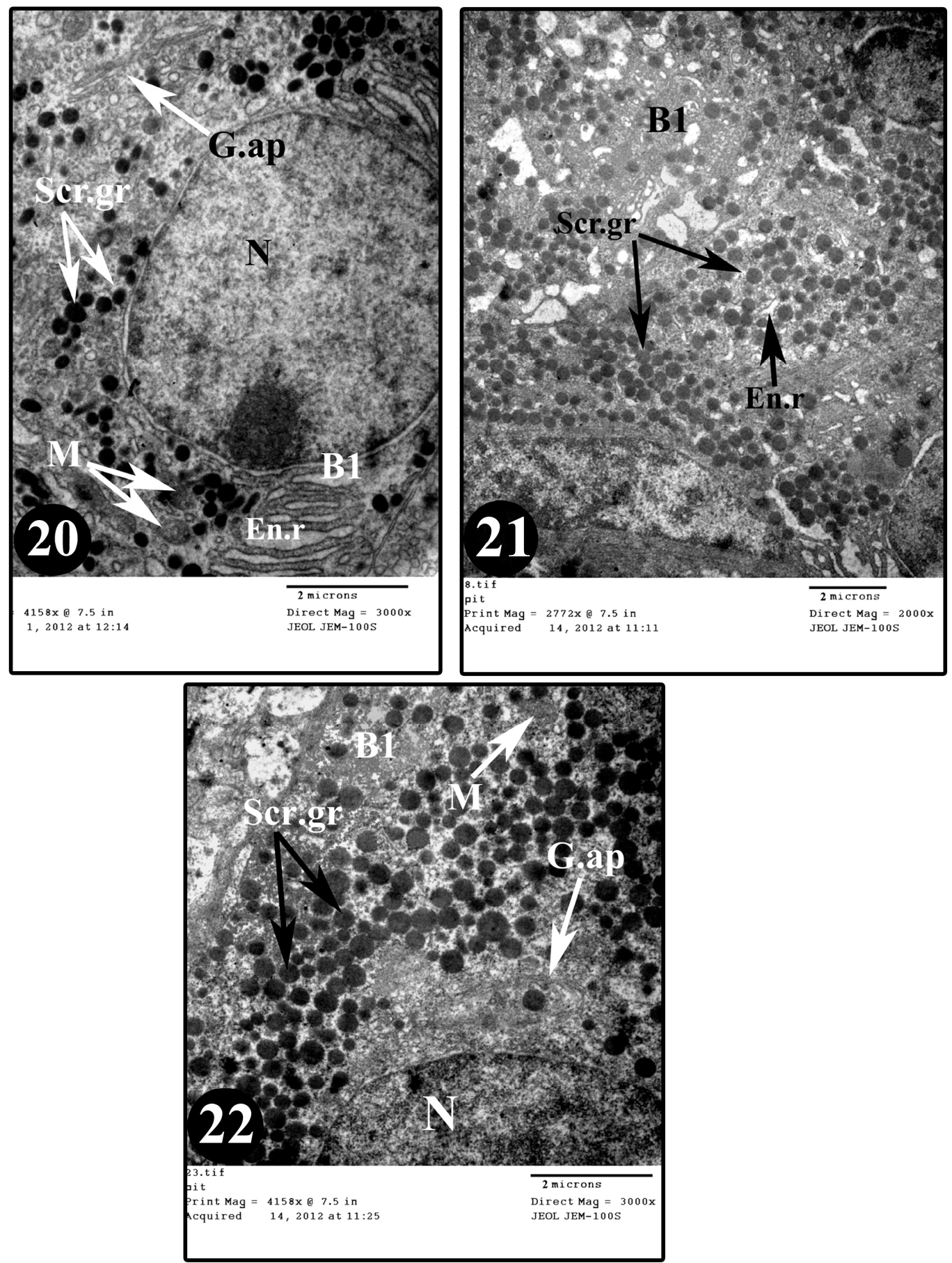


\section{ARABIC SUMMARY}

دراسات مورفولوجية ونسيجية على الغدة النخامية فى أسماك السهلية من خليج السويس السيس

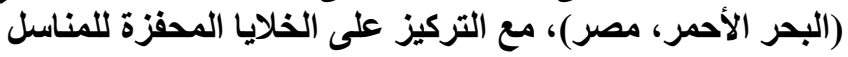

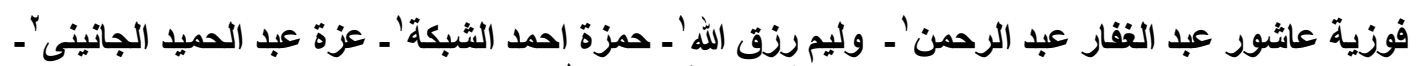

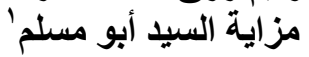

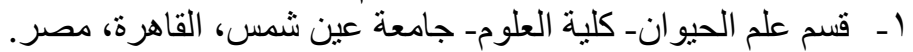

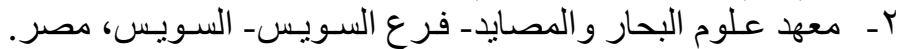

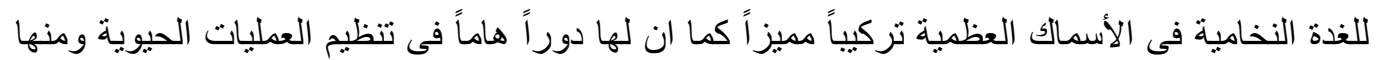

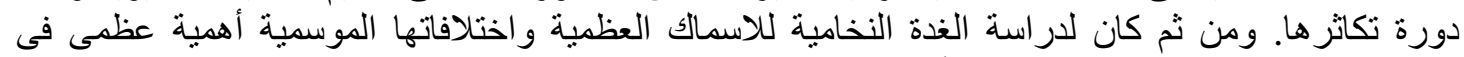

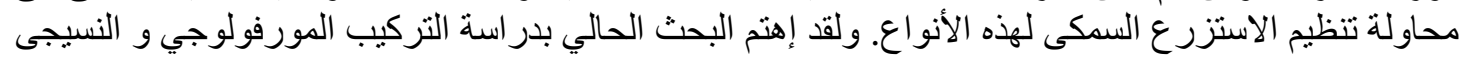

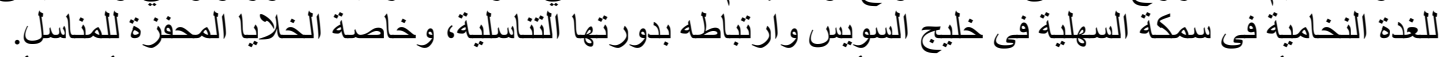

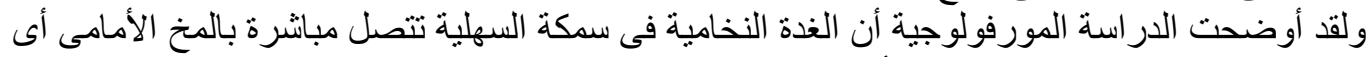

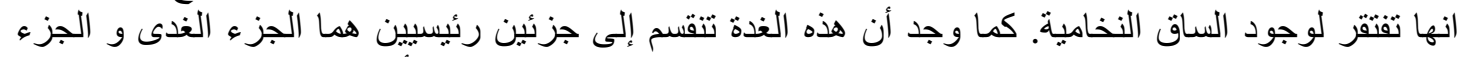

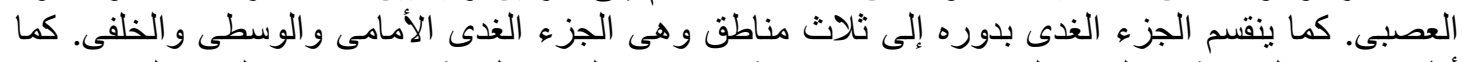

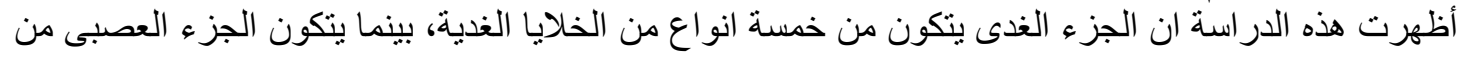
نسيج عصبى و افرازات عصبية.

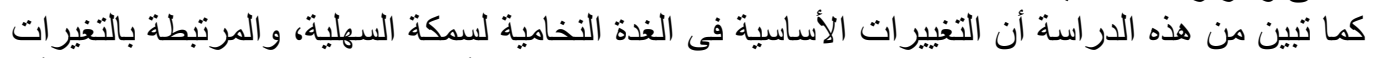

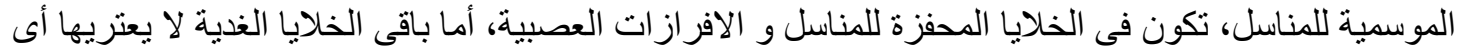
تغيير ملحوظ. 